\title{
Weaning age of calves fed a high milk allowance by automated feeders: Effects on feed, water, and energy intake, behavioral signs of hunger, and weight gains
}

\section{A. M. de Passillé, ${ }^{* 1}$ T. F. Borderas, ${ }^{*} \dagger$ and J. Rushen*}

*Pacific Agri-Food Research Centre, Agriculture and Agri-Food Canada, Agassiz, British Columbia, Canada V0M 1A0

†Departamento de producción agrícola y animal, Universidad Autónoma Metropolitana Unidad Xochimilco, Coyoacán CP 04960, Mexico

\section{ABSTRACT}

Dairy calves are increasingly fed large volumes of milk, which reduces feeding motivation and improves weight gain. However, calves often show signs of hunger and lose weight when weaned off milk due to low starter intake. We examined whether delaying the age at weaning would reduce responses to weaning. Calves were raised in groups of 9 and fed milk, starter, hay, and water with automated feeders. In each group, 3 calves were randomly assigned to 1 of 3 treatments: (1) low-milk, early-weaned: fed $6 \mathrm{~L} / \mathrm{d}$ of milk and weaned at $47 \mathrm{~d}$ of age; (2) high-milk early-weaned: fed $12 \mathrm{~L} / \mathrm{d}$ of milk and weaned at $47 \mathrm{~d}$; (3) high-milk later-weaned: fed $12 \mathrm{~L} / \mathrm{d}$ of milk and weaned at $89 \mathrm{~d}$ of age. Milk, starter, and hay intakes were recorded daily and digestible energy (DE) intake estimated. Feeder visits were recorded. Before weaning, the high-milk calves drank more milk, ate less starter and hay, but had higher DE intakes, gained more weight, and made fewer visits to the milk feeder than the low-milk, early-weaned calves. During and immediately after weaning, the high-fed, early-weaned calves ate less starter and hay, had lower DE intakes, and gained less weight than the low-milk, early-weaned calves and lost their body weight advantage $7 \mathrm{~d}$ after weaning. During and immediately after weaning, the high-milk, later-weaned calves ate more starter and hay and had higher DE intakes, higher weight gains, and made fewer visits to the milk feeder than the high-milk, early-weaned calves. They were still heavier than the low-milk, early-weaned calves 18 $\mathrm{d}$ after weaning. Delaying the age at which calves are weaned off milk reduces the drop in energy intake and behavioral signs of hunger that result from weaning.

Key words: dairy calf, energy intake, hunger, weaning

Received May 16, 2010.

Accepted October 19, 2010

${ }^{1}$ Corresponding author: annemarie.depassille@agr.gc.ca

\section{INTRODUCTION}

Owing to the high labor demands of calf rearing, there is growing interest in automated feeding systems, which reduce labor, allow for a more flexible approach to feeding calves, and facilitate the feeding of larger amounts of milk (Hammon et al., 2002; Hepola, 2003; Roth et al., 2009a). There is growing interest in feeding calves an increased quantity of milk or replacer in the first weeks of life as this improves growth rates (Jasper and Weary, 2002; Drackley, 2008) and reduces behavioral signs of hunger (Hammon et al., 2002; Jensen, 2006; De Paula Vieira et al., 2008). However, feeding large amounts of milk reduces starter intake, which can lead to weight loss at weaning (e.g., Sweeney et al., 2010), reducing the growth advantages of higher milk rations (Huuskonen and Khalili, 2008; Morrison et al., 2009). Gradual weaning can increase starter intake and lead to improved energy intakes during and after weaning (Khan et al., 2007; Sweeney et al., 2010). However, de Passillé et al. (2010) reported that digestible energy (DE) intakes still decreased with gradual weaning at 6 wk of age, and considerable cross sucking was observed, which was not reported by Roth et al. (2009b) among calves weaned at 11 to $12 \mathrm{wk}$ of age. This suggests that the age at weaning can influence the effects of weaning on high-milk-fed calves. Considerable variation exists among farms and among countries as to when dairy calves are weaned off milk. North American dairy herds most commonly wean between 6 and 8 wk of age (USDA, 2010; Vasseur et al., 2010), but weaning around $12 \mathrm{wk}$ is practiced in some herds (USDA, 2010; Vasseur et al., 2010), and in some European countries (e.g., Roth et al., 2009a). However, little research has been done on the effects of different ages at weaning.

Although providing water to milk-fed calves is often recommended, little solid data exists on water intakes by calves (Drackley, 2008). Milk-fed calves drink little water until weaning, at which time water intake increases markedly (Hepola et al., 2008), and water intake tends to follow the intake of solid food (Kertz et al., 1984). 
The aim of this study was to examine the effect of age of weaning on feed, water, and DE intake, and the occurrence of behavioral signs of hunger and weight gains during and after weaning of calves fed large quantities of milk via automated feeders.

\section{MATERIALS AND METHODS}

This study was conducted at the UBC Dairy Education and Research Centre in Agassiz, BC, Canada. The Institutional Animal Care Committee (monitored by the Canadian Council for Animal Care) approved all procedures described in this study.

\section{Housing and Management}

Fifty-four female Holstein calves [BW (mean \pm SD) $=42.25 \pm 4.66 \mathrm{~kg}]$ were fed $4 \mathrm{~L}$ of colostrum within 6 $\mathrm{h}$ after birth. Within $24 \mathrm{~h}$ of birth, calves were weighed and moved into individual sawdust-bedded pens (1.22 $\mathrm{m} \times 2.44 \mathrm{~m}$ ), where they were bottle fed $6 \mathrm{~L}$ of whole milk/d and had ad libitum access to water in buckets.

At 4 to $6 \mathrm{~d}$ of age $($ mean $=5.4 \mathrm{~d})$, the calves were moved into $4.87 \mathrm{~m} \times 7.31 \mathrm{~m}$ sawdust-bedded pens with a partially slatted floor that could hold groups of 9 calves (described in Sweeney et al., 2010). Fresh bedding was added to each pen once per week. Calves were fed pasteurized waste and some pasteurized, saleable milk (herd averages of $3.97 \%$ fat, $4.10 \%$ protein, $3.30 \%$ lactose from bulk-tank samples) at $40^{\circ} \mathrm{C}$ and had ad libitum access to a textured calf starter $(\mathrm{CP}=17.9 \%$ on a DM basis, with the main ingredients being $16 \%$ wheat, $14 \%$ barley, $13 \%$ canola meal, $13 \%$ oats, $10 \%$ soy, $10 \%$ corn, and $4 \%$ molasses; Unifeed Ltd., Chilliwack, BC, Canada) from automated feeders supplying milk and starter, with both feeders controlled by a single computer (CF 1000 CS Combi, DeLaval Inc., Tumba, Sweden). Grass hay (DM $=90.8 \%$; $\mathrm{CP}=15.1 \%$; NDF $=51.1 \% ; \mathrm{ADF}=33.6 \%)$ and water were available ad libitum from automated feeders that weighed the intake of each calf at each meal (RIC, Insentec B. V. Marknesse, the Netherlands). All calves were weighed once a week (Smart1 Scales, Westernscale Inc., Port Coquitlam, BC, Canada). The calves remained in the pens with access to the same starter and hay until between 16 and 18 wk of age.

\section{Experimental Treatments}

Upon being moved into group pens, the calves were assigned to 1 of 3 different treatments balancing for birth weight and age. In the low-milk, early-weaned treatment, calves were allowed $6 \mathrm{~L}$ of milk/d from arrival in the group pen until d 38 . On d 39 , milk allow- ance was gradually decreased using the automated milk feeder program until weaning was completed on d 47, when no milk was available for the calves. In the highmilk, early-weaned treatment, the calves were fed $12 \mathrm{~L}$ of milk/d from arrival in the group pens until weaning began on d 39 and the calves were fully weaned on $d$ 47. In the high-milk, later weaning treatment, calves were fed $12 \mathrm{~L}$ of milk/d from arrival in the group pens until d 80. Milk was gradually reduced until d 89 when no milk was available to the calves. Each pen contained 3 calves from each treatment. We choose these ages because 6 -wk weaning is normal practice for this farm and is common in North American dairy herds (USDA, 2010; Vasseur et al., 2010). Weaning around $12 \mathrm{wk}$ is practiced in some North American dairy herds (USDA, 2010; Vasseur et al., 2010), some European countries (e.g., Roth et al., 2009a), and in organic dairy production.

\section{Data Analysis}

The quantities of milk, starter, hay, and water consumed by each calf at each meal were automatically recorded and converted to daily intakes. A full data set was available for only 51 calves. To integrate the intakes of milk, starter, and hay, daily DE intake for each individual calf was estimated. Four samples of calf starter and 2 samples of hay were analyzed (Bodycote Testing Group Inc., Lethbridge, AB, Canada), and the mean DE content that was calculated from the analyzed chemical constituents was $3.48 \mathrm{Mcal} / \mathrm{kg}$ for starter and $2.40 \mathrm{Mcal} / \mathrm{kg}$ for hay. Milk was estimated to contain $5.59 \mathrm{Mcal} / \mathrm{kg}$ of DE (NRC, 2001).

Mean values for daily intake of milk, starter, hay, water, and DE were calculated for either each day or each week of age, depending on the analysis. The mean daily number of visits by each calf to the milk feeder was calculated from data from the milk feeders. To test the effects of the treatments on responses to weaning, we used PROC GLM with group and treatment as factors and the group $\times$ treatment interactions. The analysis was done separately for 4 age periods. The first period (preweaning) was from d 10 to $\mathrm{d} 38$ of age, before any calves had been weaned. The second period (during weaning) included the $8 \mathrm{~d}$ when milk was gradually reduced (from d 39 to $\mathrm{d} 46$ for the 2 early-weaned treatments, and from d 81 to $\mathrm{d} 88$ for the later-weaned treatment). The third period (postweaning) included the $7 \mathrm{~d}$ after weaning was concluded ( $\mathrm{d} 47$ to $\mathrm{d} 53$ for the 2 early-weaned treatments, and from d 89 to d 95 for the later-weaned treatment). The fourth period included the $7 \mathrm{~d}$ before the later-weaned calves began to be weaned (d 74 to d 80). For this analysis, we expressed all intakes and weight gain as a function 


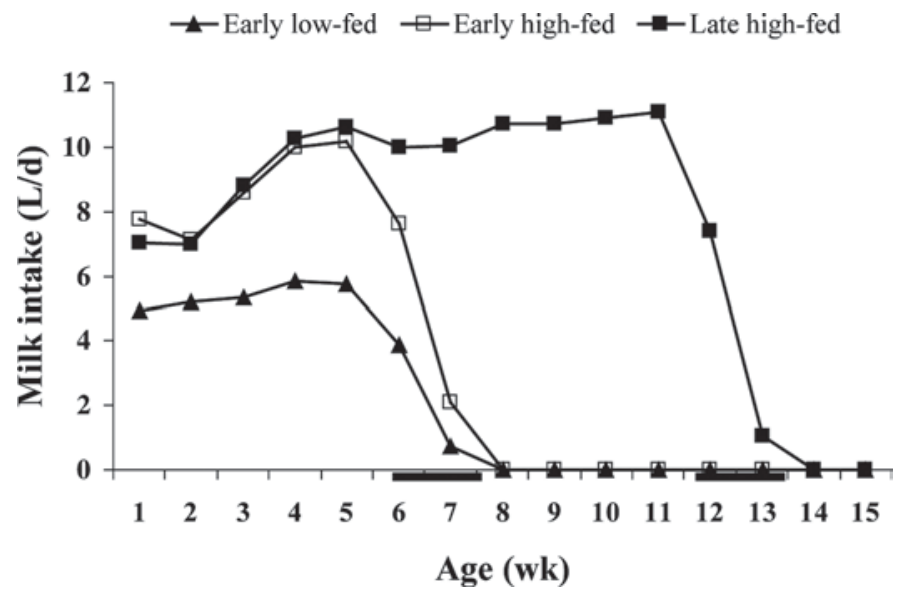

Figure 1. Mean milk intake for low-milk, early-weaned calves; high-milk, early-weaned calves; and high-milk, later-weaned calves at each week of the experiment. The calves were, on average, $5 \mathrm{~d}$ old when the experiment began on wk 1 . The horizontal bars indicate the weeks when weaning was occurring. Standard deviations ranged from 0.70 on wk 1 to 0.49 on wk 8 .

of kilograms of BW to account for differences between treatments and ages in BW. The PROC GLM with the same model also was used to test differences in BW on d 5, 38, 47, 54, 79, 90, 97, and 107. During the weaning and postweaning periods, the correlations between the intakes of milk, starter, hay, and water, and the correlation between DE intake and the frequency of visits to the milk feeder were examined using PROC CORR.

\section{RESULTS}

Figures 1, 2, 3 and 4 show the mean daily intakes of milk, starter, hay, and water, and Figure 5 shows the

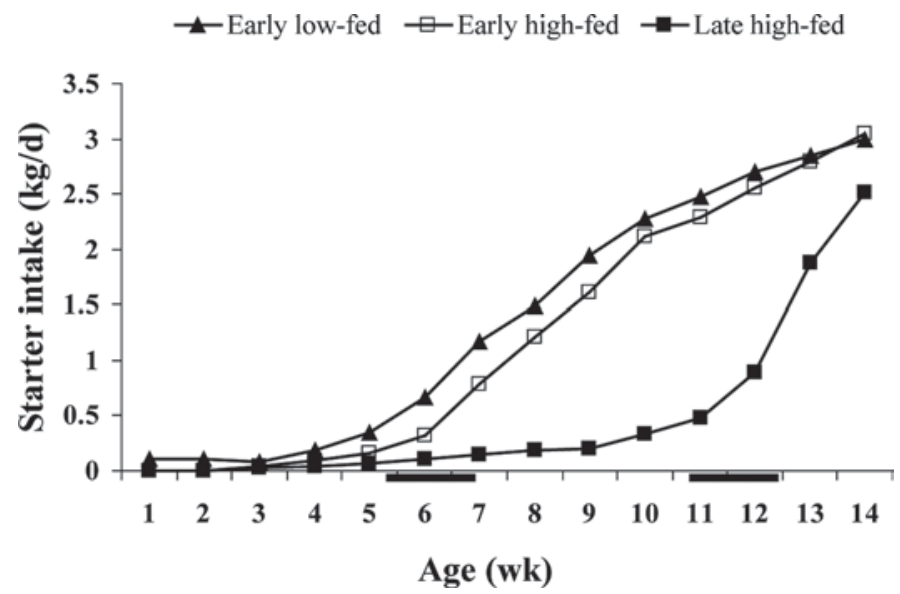

Figure 2. Mean starter intake for low-milk, early-weaned calves; high-milk, early-weaned calves; and high-milk, later-weaned calves at each week of the experiment. The calves were, on average, $5 \mathrm{~d}$ old when the experiment began on wk 1 . The horizontal bars indicate the weeks when weaning was occurring. Standard deviations ranged from 0.12 on wk 4 to 0.95 on wk 14 . daily frequency of visits to the milk feeder of the calves for the 3 treatments during each week. Starter and hay intakes were relatively low before weaning. For the early-weaned calves, starter intakes increased with weaning. Among the high-milk later-weaned calves, starter intake increased before weaning until mean intakes were close to $0.5 \mathrm{~kg} / \mathrm{d}$. Starter intake then increased rapidly with weaning. Hay intake increased progressively after wk 4 in all 3 treatments. Water intake for all treatment groups remained low until weaning, when it increased sharply.

Prior to weaning, the low-fed calves made many more visits to the milk feeder than the high-milk calves. During this period, $73 \%$ of the visits by the low-fed calves were un-rewarded in that the calves received no milk. When weaning began, the high-milk, early-weaned calves increased their visits to the milk feeder. When weaning was complete, the calves of both early-weaned treatments reduced the frequency of visits to the milk feeder, but they continued to visit occasionally throughout the study. The high-milk, later-weaned calves showed a slight increase in visits when they began to be weaned.

Between d 10 and d 38 of age, before any calves had begun to be weaned, the low-fed calves drank less milk, ate more starter and hay, had lower DE intakes, gained less weight (all as a function of BW) and made more visits to the milk feeder than the high-milk calves (Table 1). During this period, the frequency of visits to the milk feeder was negatively correlated with $\mathrm{DE}$ intake of each calf $(\mathrm{r}=-0.69 ; P<0.001)$. No differences in water intake were found. Milk intake was negatively correlated with starter intake $(\mathrm{r}=-0.61$;

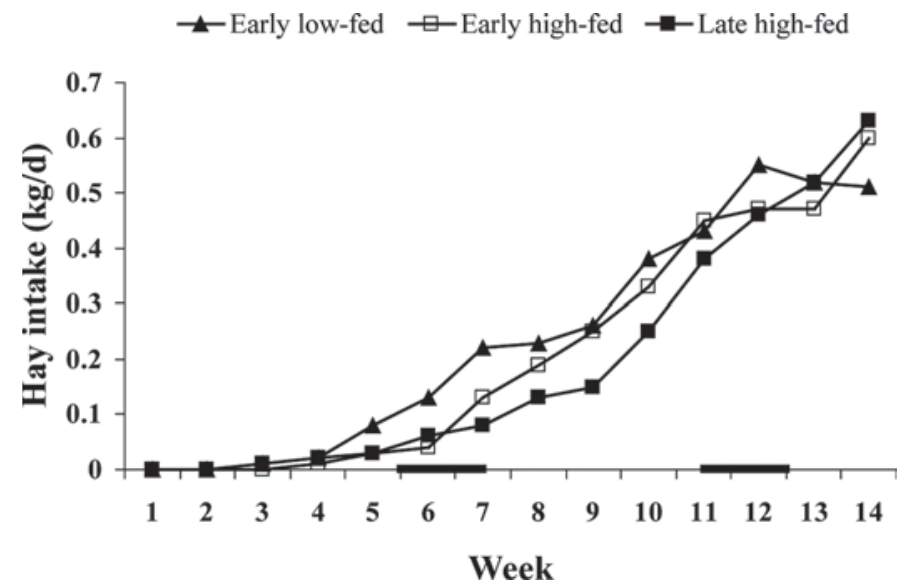

Figure 3. Mean hay intake for low-milk, early-weaned calves; highmilk, early-weaned calves; and high-milk, later-weaned calves at each week of the experiment. The calves were, on average, $5 \mathrm{~d}$ old when the experiment began on wk 1 . The horizontal bars indicate the weeks when weaning was occurring. Standard deviations ranged from 0.02 on wk 1 to 0.33 on wk 14 . 
Table 1. Least squares means $( \pm \mathrm{SE})$ of weight gain (expressed as a function of BW) and daily intakes of milk, starter, hay digestible energy, and water of low-fed calves and high-fed calves during the period from d 10 to $\mathrm{d}$ 38 of age before any calves were being weaned

\begin{tabular}{lrcc}
\hline Item & \multicolumn{1}{c}{ Low-fed } & \multicolumn{1}{c}{ High-fed $^{1}$} & $P$-value \\
\hline Milk intake $\left(\mathrm{g} / \mathrm{kg}\right.$ of BW $\left.{ }^{2}\right)$ & $104.79 \pm 2.61$ & $150.83 \pm 1.85$ & $<0.001$ \\
Starter intake $(\mathrm{g} / \mathrm{kg}$ of $\mathrm{BW})$ & $2.78 \pm 0.31$ & $0.86 \pm 0.22$ & $<0.001$ \\
Hay intake $(\mathrm{g} / \mathrm{kg}$ of BW) & $0.54 \pm 0.10$ & $0.22 \pm 0.07$ & 0.01 \\
Digestible energy intake $(\mathrm{kcal} / \mathrm{kg}$ of BW) & $80.66 \pm 1.79$ & $105.17 \pm 1.26$ & $<0.001$ \\
Water intake $(\mathrm{g} / \mathrm{kg}$ of BW) & $3.31 \pm 1.40$ & $1.30 \pm 1.00$ & 0.25 \\
Weight gain $(\%$ of BW) & $1.16 \pm 0.06$ & $1.47 \pm 0.04$ & $<0.001$ \\
Visits to milk feeder $($ no. $/ \mathrm{d})$ & $18.2 \pm 0.90$ & $7.0 \pm 0.64$ & $<0.001$ \\
\hline
\end{tabular}

${ }^{1}$ Combining high-fed early-weaned and high-fed late-weaned calves.

${ }^{2}$ Mean BW during this period: low-fed calves $=53.8 \mathrm{~kg}$; high-fed calves $=60.9 \mathrm{~kg}$.

$P<0.001)$, less so with hay intake $(\mathrm{r}=-0.42 ; P=$ $0.003)$ and water intake $(\mathrm{r}=-0.28 ; P=0.04)$. Starter and hay intakes were not strongly correlated $(\mathrm{r}=0.21$; $P<0.10)$. Water intake was positively correlated with starter intake $(\mathrm{r}=0.30 ; P=0.03)$, but not with hay intake $(\mathrm{r}=0.02 ; P>0.10)$

Table 2 shows the intake of milk, starter, hay, water, and $\mathrm{DE}$ of calves (expressed as a function of their BW) in the 3 treatments during the weaning and immediate postweaning periods. During weaning, calves in the high-milk, early-weaned treatment drank more milk but ate less starter than the low-milk, early-weaned calves, whereas hay or total DE intakes did not differ. A significant effect of treatment on weight gains was observed during weaning $(P<0.001)$ and immediately after weaning $(P<0.001)$. Weight gains were greater for the low-milk, early-weaned calves than the high-milk, early-weaned calves. Two calves in the high-milk, earlyweaned group and 1 calf in the low-milk, early-weaned

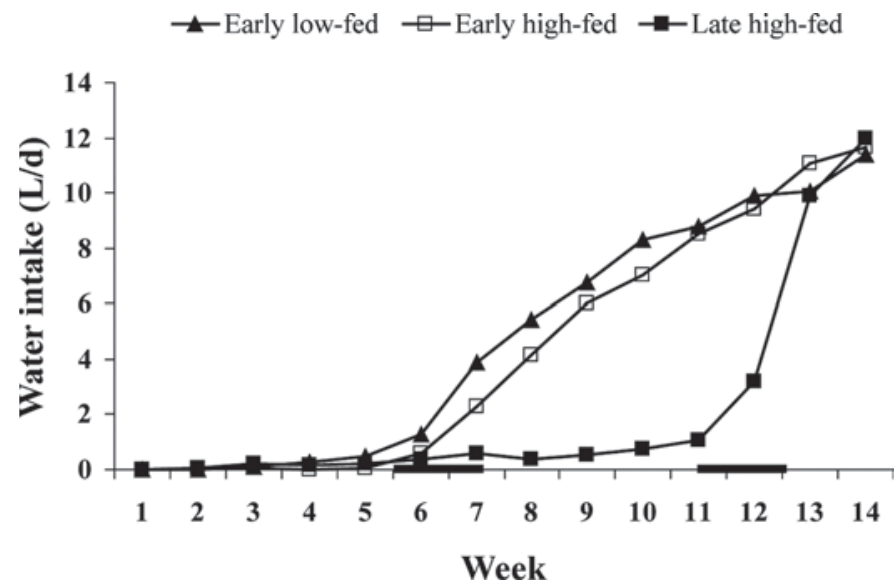

Figure 4. Mean water intake for low-milk, early-weaned calves; high-milk, early-weaned calves; and high-milk, later-weaned calves at each week of the experiment. The calves were, on average, $5 \mathrm{~d}$ old when the experiment began on wk 1 . The horizontal bars indicate the weeks when weaning was occurring. Standard deviations ranged from 0.70 on wk 1 to 6.20 on wk 14 . groups lost weight (Figure 6). However, the treatment averages concealed the large variation in weight gains among calves within treatments (Figure 6).

Between d 74 and 80 (36 d to $42 \mathrm{~d}$ after weaning was complete for the early-weaned calves), intakes (expressed as a function of BW) did not differ between the high-milk, early-weaned and the low-milk, earlyweaned calves, although the latter had higher weight gains (Table 3). In fact, the weight gains of the lowmilk, early-weaned calves were higher than the highmilk, later-weaned calves, which had not yet begun to be weaned (Table 3 ).

During their weaning period, the high-milk, laterweaned calves drank less milk, but ate more starter and hay and had higher DE intakes and better weight gains (all corrected for BW differences due to age) than the high-milk, early-weaned calves during their weaning period. However, they made the same number of visits to the milk feeder (Table 2; Figure 6). Their weight

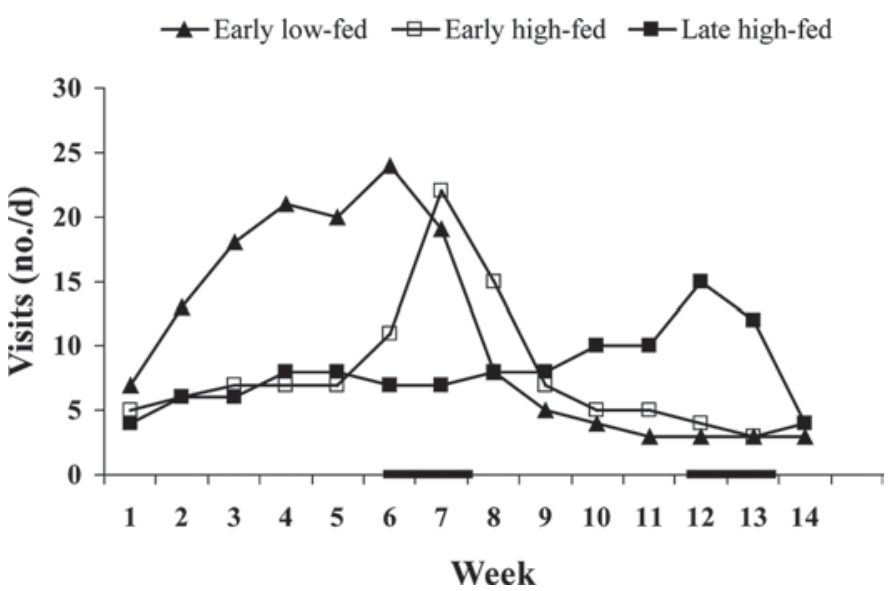

Figure 5. Mean daily frequency of visits to the milk feeder by lowmilk, early-weaned calves; high-milk, early-weaned calves; and highmilk, later-weaned calves at each week of the experiment. The calves were, on average, $5 \mathrm{~d}$ old when the experiment began on wk 1 . The horizontal bars indicate the weeks when weaning was occurring. 


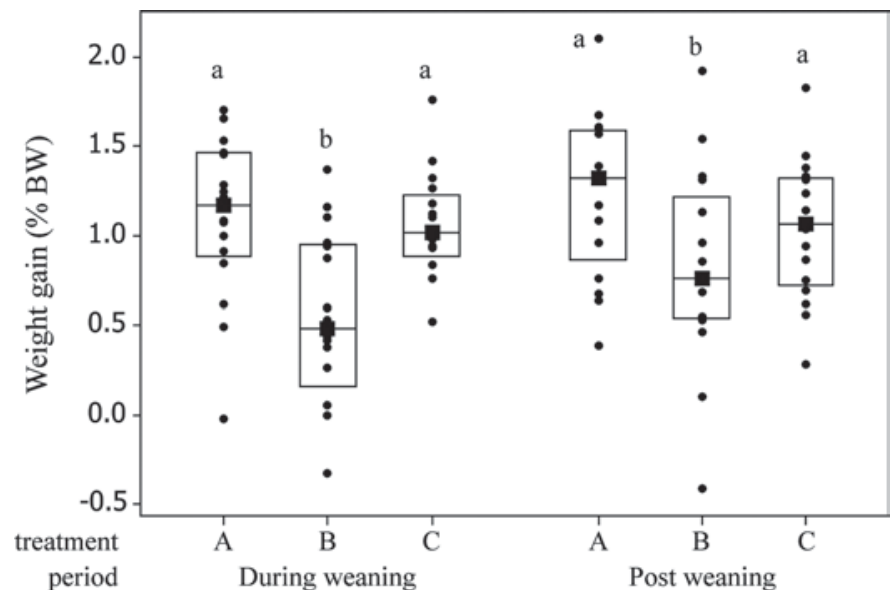

Figure 6. Weight gains (\% BW) of low-milk, early-weaned calves (treatment A); high-milk, early-weaned calves (treatment B); and highmilk, later-weaned calves (treatment $\mathrm{C}$ ) during the weaning period $(\mathrm{d}$ 39 to 46 for early-weaned calves, d 74 to 80 for later-weaned calves) and immediate postweaning period (d 47 to 53 for early-weaned calves, d 89 to 95 for later-weaned calves). Each point represents an individual calf, whereas the box plot shows the median and 25th and 75th percentile of weight gains for each treatment. ${ }^{\mathrm{a}, \mathrm{b}}$ Treatments with different letters differ significantly within period.

gains were similar to the low-milk, early-weaned calves (Figure 6). During the weaning period, milk intake was negatively correlated with intake of starter $(\mathrm{r}=$ $-0.67 ; P<0.001$ ), and less so with the intake of hay (r $=-0.41 ; P=0.003)$. Intakes of hay and starter were uncorrelated $(\mathrm{r}=0.07 ; P>0.10)$. Water intake was positively correlated with starter $(\mathrm{r}=0.58 ; P<0.001)$ and hay intake $(\mathrm{r}=0.31 ; P=0.02)$, and negatively correlated with milk intake $(\mathrm{r}=-0.60 ; P<0.001)$.

During the immediate postweaning period, the highmilk, later-weaned calves had higher intakes of starter, hay, and overall DE, higher water intakes, and better weight gains (as a function of BW) than the highmilk, early-weaned calves had during their immediate postweaning period (Table 2; Figure 6). They also made fewer visits to the milk feeder. The performance of the high-milk, later-weaned calves was similar to the low-milk, early-weaned calves during the immediate postweaning period (Table 2; Figure 6). No high-milk, later-weaned calves lost weight during or after weaning. However, again, considerable variation occurred among calves in weight gain during and after weaning (Figure 6 ). During the postweaning period, intakes of hay and starter were uncorrelated $(\mathrm{r}=-0.02 ; P>0.10)$. Water intake was positively correlated with starter intake $(\mathrm{r}=$ $0.43 ; P<0.001)$ and tended to be correlated with hay intake $(\mathrm{r}=0.26 ; P=0.07)$. During the postweaning period, the frequency of visits to the milk feeder was negatively correlated with DE intake $(\mathrm{r}=-0.45 ; P<$ 0.001).

During the final week that the calves were in the calf barn (d 101 to d 107), no differences were found between the 3 treatments in weight gain (low-milk, early-weaned $=0.72 \%$ BW; high-milk, early-weaned $=$ $0.69 \% \mathrm{BW}$; high-milk, later-weaned $=0.63 \% \mathrm{BW} ; \mathrm{SE}$ $=0.09 \% \mathrm{BW} ; P=0.76)$. Table 4 shows the BW of the calves in the 3 treatment groups. The high-milk calves

Table 2. Least squares means $( \pm \mathrm{SE})$ of daily intakes of milk, starter, hay, water, and estimated digestible energy (DE; expressed as a function of BW), and frequency of visits to the milk feeders of low-fed, early-weaned; high-fed, early-weaned; and high-fed, later-weaned calves during the weaning period, when the milk allowance was being progressively reduced, and during the postweaning period, $7 \mathrm{~d}$ after weaning was complete

\begin{tabular}{|c|c|c|c|c|c|}
\hline Item & $\begin{array}{c}\text { Early } \\
\text { low-fed }\end{array}$ & $\begin{array}{c}\text { Early } \\
\text { high-fed }\end{array}$ & $\begin{array}{c}\text { Later } \\
\text { high-fed }\end{array}$ & $\begin{array}{l}\text { Pooled } \\
\text { SE }\end{array}$ & $P$-value \\
\hline \multicolumn{6}{|l|}{ Weaning $^{1}$} \\
\hline Milk intake $\left(\mathrm{g} / \mathrm{kg}\right.$ of $\left.\mathrm{BW}^{2}\right)$ & $44.94^{\mathrm{a}}$ & $75.62^{\mathrm{b}}$ & $44.64^{\mathrm{a}}$ & 2.27 & $<0.001$ \\
\hline Starter intake $(\mathrm{g} / \mathrm{kg}$ of $\mathrm{BW})$ & $11.58^{\mathrm{a}}$ & $4.97^{\mathrm{b}}$ & $8.78^{\mathrm{c}}$ & 0.83 & $<0.001$ \\
\hline Hay intake ( $\mathrm{g} / \mathrm{kg}$ of $\mathrm{BW})$ & $2.00^{\mathrm{a}}$ & $0.78^{\mathrm{b}}$ & $3.87^{\mathrm{c}}$ & 0.34 & $<0.001$ \\
\hline DE intake $(\mathrm{kcal} / \mathrm{kg}$ of $\mathrm{BW})$ & 70.50 & 68.17 & 65.50 & 2.35 & 0.33 \\
\hline Water intake ( $\mathrm{g} / \mathrm{kg}$ of $\mathrm{BW})$ & $24.47^{\mathrm{a}}$ & $7.2^{\mathrm{b}}$ & $3.29^{\mathrm{b}}$ & 5.00 & $<0.001$ \\
\hline Visits to feeder (frequency/d) & $26.1^{\mathrm{a}}$ & $17.5^{\mathrm{b}}$ & $17.2^{\mathrm{b}}$ & 1.53 & $<0.001$ \\
\hline \multicolumn{6}{|l|}{ Postweaning $^{3}$} \\
\hline Starter intake $\left(\mathrm{g} / \mathrm{kg}\right.$ of $\left.\mathrm{BW}^{4}\right)$ & $17.68^{\mathrm{a}}$ & $11.74^{\mathrm{b}}$ & $16.61^{\mathrm{a}}$ & 1.25 & 0.004 \\
\hline Hay intake $(\mathrm{g} / \mathrm{kg}$ of $\mathrm{BW})$ & $3.64^{\mathrm{a}, \mathrm{b}}$ & $2.43^{\mathrm{b}}$ & $4.53^{\mathrm{a}}$ & 0.49 & 0.017 \\
\hline DE intake $(\mathrm{kcal} / \mathrm{kg}$ of $\mathrm{BW})$ & $62.92^{\mathrm{a}}$ & $43.27^{\mathrm{b}}$ & $61.28^{\mathrm{a}}$ & 3.76 & $<0.001$ \\
\hline Water intake $(\mathrm{g} / \mathrm{kg}$ of $\mathrm{BW})$ & $67.67^{\mathrm{a}}$ & $42.45^{\mathrm{b}}$ & $88.57^{\mathrm{c}}$ & 6.57 & $<0.001$ \\
\hline Visits to feeder (frequency/d) & $11.8^{\mathrm{a}}$ & $21.5^{\mathrm{b}}$ & $7.2^{\mathrm{a}}$ & 1.8 & $<0.001$ \\
\hline
\end{tabular}

${ }^{\mathrm{a}-\mathrm{c}}$ Treatments within the same row with different superscripts are significantly different, $P<0.05$.

${ }^{1}$ Day 39 to 46 for early-weaned calves, d 74 to 80 for later-weaned calves.

${ }^{2}$ Mean BW during this period: low-fed, early-weaned calves = $67.3 \mathrm{~kg}$; high-fed, early-weaned calves $=76.4 \mathrm{~kg}$; high-fed, later-weaned calves $=124.9 \mathrm{~kg}$.

${ }^{3}$ Day 47 to 53 for early-weaned calves, d 89 to 95 for later-weaned calves.

${ }^{4}$ Mean BW during this period: low-fed, early-weaned calves $=73.5 \mathrm{~kg}$; high-fed, early-weaned calves $=79.7 \mathrm{~kg}$; high-fed, later-weaned calves $=135.2 \mathrm{~kg}$. 
Table 3. Least squares means $( \pm \mathrm{SE})$ of weight gain (expressed as a function of BW) and daily intakes of milk, starter, hay, digestible energy (DE), and water, and frequency of visits to the milk feeder of low-fed calves and high-fed calves during the period from d 74 to 80 , just before the beginning of weaning for the high-fed, late-weaned calves

\begin{tabular}{lccccc}
\hline Item & $\begin{array}{c}\text { Low-fed, } \\
\text { early-weaned }\end{array}$ & $\begin{array}{c}\text { High-fed, } \\
\text { early-weaned }\end{array}$ & $\begin{array}{c}\text { High-fed, } \\
\text { later-weaned }\end{array}$ & $\begin{array}{c}\text { Pooled } \\
\text { SE }\end{array}$ & $P$-value \\
\hline Milk intake $\left(\mathrm{g} / \mathrm{kg}\right.$ of BW $\left.{ }^{\mathrm{l}}\right)$ & 0 & 0 & 97.43 & 1.50 & - \\
Starter intake $(\mathrm{g} / \mathrm{kg}$ of BW) & $23.47^{\mathrm{a}}$ & $22.52^{\mathrm{a}}$ & $4.11^{\mathrm{b}}$ & 1.09 & $<0.001$ \\
Hay intake $(\mathrm{g} / \mathrm{kg}$ of BW) & 4.55 & 4.01 & 3.38 & 0.50 & 0.24 \\
DE intake $(\mathrm{kcal} / \mathrm{kg}$ of BW) & 82.39 & 79.14 & 85.89 & 3.23 & 0.35 \\
Water intake $(\mathrm{g} / \mathrm{kg}$ of BW) & $83.84^{\mathrm{a}}$ & $79.70^{\mathrm{a}}$ & $9.0^{\mathrm{b}}$ & 5.76 & $<0.001$ \\
Weight gain $(\%$ of BW) & $1.38^{\mathrm{a}}$ & $1.08^{\mathrm{b}}$ & $1.07^{\mathrm{b}}$ & 0.07 & 0.005 \\
Visits to milk feeder $($ no. $/ \mathrm{d})$ & $3.3^{\mathrm{a}}$ & $3.8^{\mathrm{a}}$ & $9.6^{\mathrm{b}}$ & 0.88 & $<0.001$ \\
\hline
\end{tabular}

${ }^{\mathrm{a}, \mathrm{b}}$ Treatments within the same row with different superscripts are significantly different $(P<0.05)$.

${ }^{1}$ Mean BW during this period: low-fed, early-weaned calves $=104.6 \mathrm{~kg}$; low-fed, early-weaned calves $=108.9$ $\mathrm{kg}$; high-fed, later-weaned calves $=114.6 \mathrm{~kg}$

were heavier before weaning then the low-fed calves, but this advantage was lost by the high-milk, early-weaned calves soon after weaning: the low-fed and high-milk, early-weaned calves did not differ significantly by d 54 (8 d after weaning was complete). Some evidence existed that the high-milk, later-weaned calves kept their BW advantage for longer after weaning, tending to still be heavier than the low-milk, early-weaned calves on $\mathrm{d}$ 107 (19 d after their weaning was complete).

\section{DISCUSSION}

Calves fed milk at about $10 \%$ of BW during the first 5 wk of life had lower DE intakes than calves fed larger volumes of milk, despite higher intakes of starter and hay. They also made many more visits to the milk feeders without obtaining milk, indicating a higher level of hunger. However, when calves fed larger volumes of milk were weaned at 6 to 7 wk of age, a decrease in DE intake occurred due to a low consumption of starter and hay, which led to reduced weight gains and weight loss by some calves. Delaying weaning until 12 to 13 wk of age effectively eliminated this decrease in energy intake and resulted in fewer signs of hunger at weaning and in the immediate postweaning period.
Milk intakes were similar to those reported previously (e.g., Jasper and Weary, 2002; Huuskonen and Khalili, 2008; Sweeney et al., 2010). Between $10 \mathrm{~d}$ and $39 \mathrm{~d}$ of age, the high-milk-fed calves drank 15\% BW of milk on average (9 to $10 \mathrm{~L} / \mathrm{d})$. For the later-weaned calves, mean milk intakes remained between 10 and $12 \mathrm{~L} / \mathrm{d}$ until weaning. The low-milk-fed calves partly compensated for the low milk allowance by increasing both starter and hay intakes. However, they did not eat enough starter or hay before 6 wk of age to compensate fully for the low allowance of milk, as DE intakes and weight gains were below than those of high-milk calves. These low DE intakes were associated with a high frequency of visits to the milk feeder, even if these did not usually result in a milk meal. A high frequency of unrewarded visits to the milk feeder is a sign of hunger or high feeding motivation (Hammon et al., 2002; Jensen 2006; De Paula Vieira et al., 2008). We found that this measure was strongly negatively correlated with the DE intake of the calf: calves that had low DE intakes made more visits to the milk feeder.

The large volumes of milk fed to the high-milk-fed calves did lead to reduced intakes of starter as reported in previous studies (Hepola, 2003; Drackley, 2008) and of hay, demonstrating that milk is the calf's preferred

Table 4. Least squares means $( \pm \mathrm{SE})$ for BW $(\mathrm{kg})$ of low-fed, early-weaned; high-fed, early-weaned; and highfed, later-weaned calves on d 5, 38, 47, 54, 79, 90, 97, and 107 of age

\begin{tabular}{lccccc}
\hline $\begin{array}{l}\text { Age } \\
\text { d) }\end{array}$ & $\begin{array}{c}\text { Low-fed, } \\
\text { early-weaned }\end{array}$ & $\begin{array}{c}\text { High-fed, } \\
\text { early-weaned }\end{array}$ & $\begin{array}{c}\text { High-fed, } \\
\text { later-weaned }\end{array}$ & $\begin{array}{c}\text { Pooled } \\
\text { SE }\end{array}$ & $P$-value \\
\hline 5 & 44.5 & 45.8 & 45.8 & 1.85 & 0.87 \\
38 & $64.4^{\mathrm{a}}$ & $74.5^{\mathrm{b}}$ & $74.9^{\mathrm{b}}$ & 1.95 & $<0.001$ \\
47 & $71.2^{\mathrm{a}}$ & $78.2^{\mathrm{b}}$ & $83.8^{\mathrm{b}}$ & 2.28 & 0.001 \\
54 & $77.6^{\mathrm{a}}$ & $83.0^{\mathrm{a}}$ & $90.6^{\mathrm{b}}$ & 2.64 & 0.004 \\
79 & $108.9^{\mathrm{a}}$ & $112.4^{\mathrm{a}, \mathrm{b}}$ & $118.6^{\mathrm{b}}$ & 3.15 & 0.09 \\
90 & $123.2^{\mathrm{a}}$ & $125.4^{\mathrm{a}}$ & $133.0^{\mathrm{b}}$ & 3.34 & 0.10 \\
97 & $130.8^{\mathrm{a}}$ & $133.3^{\mathrm{a}}$ & $140.8^{\mathrm{b}}$ & 3.40 & 0.10 \\
107 & $142.0^{\mathrm{a}}$ & $144.2^{\mathrm{a}}$ & $153.1^{\mathrm{b}}$ & 3.83 & 0.10 \\
\hline
\end{tabular}

${ }^{\mathrm{a}, \mathrm{b}}$ Treatments within the same row with different superscripts are significantly different $(P<0.05)$. 
feed at this age. Consequently, the major problem for the high-milk, early-weaned calves at weaning was that they did not increase starter or hay intakes sufficiently quickly to compensate for the loss of milk, even though the weaning was gradual. This resulted in reduced weight gains and weight loss by some calves. In contrast, once weaning began, the low-milk, early-weaned calves quickly increased their intake of both starter and hay so that DE intakes and weight gains were higher than those of the high-milk, early-weaned calves. However, a drop in DE intake was still apparent and some low-milk, early-weaned calves grew little or lost weight during the weaning period. However, by wk 11, the lowmilk, early-weaned calves had similar weight gains to the later-weaned calves that were still drinking milk.

Our results showed that delaying weaning until 12 to $13 \mathrm{wk}$ of age reduced the negative effect of weaning on DE intake and growth and reduced signs of hunger during and after weaning. The high-milk, laterweaned calves had higher starter and hay intakes, and thus higher DE intakes and weight gains, during and immediately after weaning than the high-fed, earlyweaned calves (corrected for differences in BW). They also visited the milk feeder less frequently, suggesting a lower level of hunger. During the week after weaning, the high-milk, later-weaned calves had the same starter intakes and weight gains (corrected for differences in BW) as the low-milk, early-weaned calves during their postweaning period. Previous research has found little effect of weaning age on growth from 3 to 6 wk of age (Kehoe et al., 2007). Our results show that delaying weaning until 12 to $13 \mathrm{wk}$ of age reduced the negative effect of weaning on DE intake and growth, suggesting that it may be preferable to wean calves fed large quantities of milk at a later age.

Despite the clear effects of the treatments on weight gains during and immediately after weaning, large differences were observed among calves within the same treatment in weight gain (Figure 6). These differences among individual calves in their ability to switch to a solid-food diet are often overlooked in making recommendations for weaning. Weaning according to each individual calf's ability to eat solid food is likely to be preferable to weaning at a fixed age (Roth et al., 2009a), and automated feeders do allow this with group-housed calves.

Intakes of hay were reduced by large volumes of milk, but less so than starter intakes. At each period, the negative correlation between milk intake and hay intake was less than the correlation between milk intake and starter intake. Hay intakes began to increase from wk 5 and increased steadily even for the high-milk, laterweaned calves. There is concern in the industry that providing hay to young calves will reduce starter intake
(Drackley, 2008). However, Khan et al. (2010) recently reported that, while provision of hay does somewhat reduce starter intakes of calves fed large amounts of milk, intakes of starter are still high and overall DM intake is increased. In support, we found little evidence of a marked suppression of starter intake following free access to hay. At no age were starter and hay intakes negatively correlated. Furthermore, Sweeney et al. (2010) examined calves fed similar levels of milk to our early-weaned high-milk calves but without hay. The daily intakes of starter intake for the calves during the post-weaning period in the present study (d47 to d53), when hay was available, are only slightly lower $(1.3 \mathrm{~kg}$ or $11.74 \mathrm{~g} / \mathrm{kg} \mathrm{BW}$ ) than those reported by Sweeney et al. (2010) $(1.2 \mathrm{~kg}$ or $14.6 \mathrm{~g} / \mathrm{kg} \mathrm{BW}$ during d 41 to 49$)$. Furthermore, Khan et al. (2010) reported that access to hay increases weight gain of unweaned calves. The growth of our calves during the postweaning week was higher $(0.81 \%$ BW $)$ compared with those $(0.28 \%$ BW $)$ of Sweeney et al. (2010). Thus, the free availability of hay only slightly reduced starter intakes and was not associated with lower weight gains.

Water intakes were very low when the calves were drinking milk supporting previous findings (Hepola et al., 2008). Generally water intake tended to reflect the intake of starter (Kertz et al., 1984) and less so the intake of hay: restricted feeding of milk led to higher consumption of water, water intake increased at weaning, and at each period examined, water intake and the amount of starter that was consumed were correlated.

The short-term benefits of feeding a higher volume of milk to calves have been shown clearly to be a higher weight gain (Jasper and Weary, 2002; Huuskonen and Khalili, 2008), especially during the first week or first few days (Hammon et al., 2002; Borderas et al., 2009); reduced body fat mobilization (Hammon et al., 2002); reduced behavioral signs of hunger, such as increased activity or unrewarded visits to the milk feeder (Hammon et al., 2002; De Paula Vieira et al., 2008); increased play behavior (Krachun et al., 2010); and more efficient use of automated milk feeders (Jensen, 2006; Borderas et al., 2009). Non-nutritive sucking is reduced (Jensen, 2006; De Paula Vieira et al., 2008), and some studies report reduced cross sucking (Jung and Lidfors, 2001; Roth et al., 2009b). However, whether calf health is improved is uncertain (Khan et al., 2007; Borderas et al., 2009).

In contrast, studies into the longer-term benefits of enhanced feeding or accelerated growth programs for dairy calves have produced mixed results. Some studies report improved milk production in first lactation (Drackley, 2008) or earlier reproduction (Raeth-Knight et al., 2009), whereas others do not (Morrison et al., 2009; Terré et al., 2009). The extent to which the higher 
BW are sustained also is variable from study to study (Raeth-Knight et al., 2009; Huuskonen and Kahlili, 2008; Hill et al., 2010). Our results suggest that the method of weaning can affect how long the BW advantage is maintained. When the high-milk calves drank milk, they continued to have higher BW, suggesting that the loss of the BW advantage is due mainly to the reduced weight gain of high-milk, early-weaned calves at weaning. Delaying the age at weaning increased the time that the weight advantage was retained. The highmilk, early-weaned calves had lost their BW advantage within 1 wk of being weaned, whereas the high-milk, later-weaned calves were still heavier 4 wk after weaning was completed. However, there was some evidence of compensatory growth by the low-fed calves. In the last week before the high-milk, later-weaned calves were weaned, weight gained by the low-milk, early-weaned calves were greater.

\section{ACKNOWLEDGMENTS}

We thank everyone (especially M. Robertson, S. Vickers, and G. Zdanowicz, Agriculture and Agri Food Canada, Agassiz, BC, Canada, and the staff of the UBC Dairy Education and Research Centre, Agassiz, BC, Canada) who helped in this project or who contributed ideas or suggestions (especially A. Khan, University of British Columbia, Vancouver, BC, Canada), and the Natural Sciences and Engineering Research Council of Canada (Ottawa, ON) and Agriculture and Agri-Food Canada (Ottawa, ON) for financial support.

\section{REFERENCES}

Borderas, T. F., A. M. B. de Passillé, and J. Rushen. 2009. Feeding behavior of calves fed small or large amounts of milk. J. Dairy Sci. 92:2843-2852

de Passillé, A. M., B. Sweeney, and J. Rushen. 2010. Cross-sucking and gradual weaning of dairy calves. Appl. Anim. Behav. Sci. 124:11-15.

De Paula Vieira, A. D., V. Guesdon, A. M. de Passillé, M. A. G. von Keyserlingk, and D. M. Weary. 2008. Behavioural indicators of hunger in dairy calves. Appl. Anim. Behav. Sci. 109:180-189.

Drackley, J. K. 2008. Calf nutrition from birth to breeding. Vet. Clin. N. Amer. Food. Anim. 24:55-86.

Hammon, H. M., G. Schiessler, A. Nussbaum, and J. W. Blum. 2002. Feed intake patterns, growth performance, and metabolic and endocrine traits in calves fed unlimited amounts of colostrum and milk by automate, starting in the neonatal period. J. Dairy Sci. 85:3352-3362

Hepola, H. 2003. Milk feeding systems for dairy calves in groups: Effects on feed intake, growth and health. Appl. Anim. Behav. Sci. $80: 233-243$.
Hepola, H. P., L. T. Hänninen, S. M. Raussi, P. A. Pursiainen, A. M. Aarnikoivu, and H. S. Saloniemi. 2008. Effects of providing water from a bucket or a nipple on the performance and behavior of calves fed ad libitum volumes of acidified milk replacer. J. Dairy Sci. 91:1486-1496.

Hill, T. M., H. G. Bateman, J. M. Aldrich, and R. L. Schlotterbeck. 2010. Effect of milk replacer program on digestion of nutrients in dairy calves. J. Dairy Sci. 93:1105-1115.

Huuskonen, A., and H. Khalili. 2008. Computer-controlled milk replacer feeding strategies for group-reared dairy calves. Livest. Sci 113:302-306.

Jasper, J., and D. M. Weary. 2002. Effects of ad libitum milk intake on dairy calves. J. Dairy Sci. 85:3054-3058.

Jensen, M. B. 2006. Computer-controlled milk feeding of group-housed calves: The effect of milk allowance and weaning type. J. Dairy Sci. 89:201-206.

Jung, J., and L. Lidfors. 2001. Effects of amount of milk, milk flow and access to a rubber teat on cross-sucking and non-nutritive sucking in dairy calves. Appl. Anim. Behav. Sci. 72:201-213.

Kehoe, S. I. C. D. Dechow, and A. J. Heinrichs. 2007. Effects of weaning age and milk feeding frequency on dairy calf growth, health and rumen parameters. Livest. Sci. 110:267-272.

Kertz, A. F., L. F. Reutzel, and J. H. Mahoney. 1984. Ad libitum water intake by neonatal calves and its relationship to calf starter intake, weight gain, feces score, and season. J. Dairy Sci. 67:2964-2969.

Khan, M. A., H. J. Lee, W. S. Lee, H. S. Kim, S. B. Kim, K. S. Ki, J. K. Ha, H. G. Lee, and Y. J. Choi. 2007. Pre- and postweaning performance of Holstein female calves fed milk through step-down and conventional methods. J. Dairy Sci. 90:876-885.

Khan, M. A., D. M. Weary, D. M. Veira, and M. A. G. von Keyserlingk. 2010. Effects of hay intake on calves fed high volumes of milk. J. Dairy Sci. 93(E-Suppl. 1):419. (Abstr.)

Krachun, C., J. Rushen, and A. M. de Passillé.. 2010. Play behaviour in dairy calves is reduced by weaning and by a low energy intake. Appl. Anim. Behav. Sci. 122:71-76.

Morrison, S. J., H. C. F. Wicks, R. J. Fallon, J. Twigge, L. E. R. Dawson, A. R. G. Wylie, and A. F. Carson. 2009. Effects of feeding level and protein content of milk replacer on the performance of dairy herd replacements. Animal 3:1570-1579.

NRC. 2001. Nutrient Requirements of Dairy Cattle. 7th rev. ed. Natl. Acad. Press, Washington, DC.

Raeth-Knight, M., H. Chester-Jones, S. Hayes, J. Linn, R. Larson, D. Ziegler, B. Ziegler, and N. Broadwater. 2009. Impact of conventional or intensive milk replacer programs on Holstein heifer performance through six months of age and during first lactation. J. Dairy Sci. 92:799-809.

Roth, B. A., N. M. Keil, L. Gygax, and E. Hillmann. 2009a. Influence of weaning method on health status and rumen development in dairy calves. J. Dairy Sci. 92:645-656.

Roth, B. A., N. M. Keil, L. Gygax, and E. Hillmann. 2009b. Temporal distribution of sucking behaviour in dairy calves and influence of energy balance. Appl. Anim. Behav. Sci. 119:137-142.

Sweeney, B. C., J. Rushen, D. M. Weary, and A. M. de Passillé. 2010. Duration of weaning, starter intake, and weight gain of dairy calves fed large amounts of milk. J. Dairy Sci. 93:148-152.

Terré, M., C. Tejero, and A. Bach. 2009. Long-term effects on heifer performance of an enhanced-growth feeding programme applied during the pre-weaning period. J. Dairy Res. 76:331-339.

USDA. 2010. Dairy 2007, Heifer Calf Health and Management Practices on U.S. Dairy Operations, 2007. USDA, Fort Collins, CO.

Vasseur, E., F. Borderas, R. I. Cue, D. Lefebvre, D. Pellerin, J. Rushen, K. M. Wade, and A. M. de Passillé. 2010. A survey of dairy calf management practices in Canada that affect animal welfare. J. Dairy Sci. 93:1307-1315. 